УДК 792.028

Хлистун Олена Сергї̈вна

кандидат мистеитвознавства, дочент, Київський Національний університет культури і мистецттв,

Київ, Украӥна with_joy@ukr.net

\title{
СИСТЕМА К. С. СТАНІСЛАВСЬКОГО ЯК МЕТОДОЛОГІЧНА ОСНОВА МИСТЕЦТВА СЦЕНІЧНОГО ПЕРЕВТІЛЕННЯ
}

Мета роботи - обгрунтувати значення системи К. Станіславського як методологічної основи мистецтва сценічного перевтілення. Методологія дослідження базується на принципах системності з використанням аналітичного, класифікації, історико-типологічного методів дослідження. Наукову новизну становить аналіз системи К. Станіславського як методологічної основи майстерності перевтілення актора в художній образ. Висновки. К. С. Станіславський створив практично й науково обгрунтовану теорію образного перевтілення актора, яка має назву «Система Станіславського», що сформувала цілі покоління талановитих акторів і режисерів в Україні та за кордоном. Перетворення конкретної людини в психічну реальність іншої людини, нетривалий процес ідентифікації з нею, тимчасове виконання ії соціальнорольових функцій і $є$ перевтіленням в образ. Успішність цього процесу пов'язана 3 переживанням актора своєї ролі, яке визначається особистістю самого актора, ставленням до життєвої правди на сцені, конкретними надзавданнями для реалізації певної дії, пропонованими обставинами ролі та п’єси, колективною природою сценічного мистецтва загалом, яке об’єктивується в творчій діяльності актора одночасно як виконавця і як актора.

Ключові слова: система Станіславського, Станіславський, метод, мистецтво, актор, роль, сценічне перевтілення, переживання, надзавдання, пропоновані обставини.

Хлистун Елена Сергеевна кандидат искусствоведения, Киевский Национальный университет культуры и искусств, Киев, Украина

Система К. С. Станиславского как методологическая основа искусства сценического перевоплощения

Цель работы - обосновать значение системы К. Станиславского как методологической основы искусства сценического перевоплощения. Методо- 
логия исследования базируется на принципах системности с использованием аналитического, классификации, историко-типологического методов исследования. Научную новизну составляет анализ системы К. Станиславского как методологической основы мастерства перевоплощения актера в художественный образ. Выводы. К. С. Станиславский создал практически и научно обоснованную теорию образного перевоплощения актера, известной под названием «Система Станиславского», которая сформировала целые поколения талантливых актеров и режиссеров в Украине и за рубежом. Вживание конкретного человека в психическую реальность другого человека, непродолжительный процесс идентификации с ним, временное выполнение его социально-ролевых функций и является перевоплощением в образ. Успешность этого процесса связана с переживанием актера своей роли, которое определяется личностью самого актера, его отношением к жизненной правде на сцене, конкретными сверхзадачами для реализации определенного действия, предлагаемыми обстоятельствами роли и пьесы, коллективной природой сценического искусства в целом, которое объективируется в творческой деятельности актера одновременно как исполнителя и как актера.

Ключевые слова: система Станиславского, Станиславский, метод, искусство, актер, роль, сценическое перевоплощение, переживание, сверхзадача, предлагаемые обстоятельства.

Khlystun Olena, PhD of Arts Study, Kyiv National University of Culture and Arts, Kyiv, Ukraine

\section{Stanislavski's system as the methodological basis of the art of stage impersonation}

The purpose of the article is to substantiate the significance of Stanislavski's system as the methodological basis of the art of stage impersonation. The research methodology was based on the principles of consistency, using the analytical, classification, historical and typological methods of research. The scientific novelty of the work lies in the analysis of Stanislavski's system as the methodological basis of the skill of actor's impersonation of an artistic image. Conclusions. K. Stanislavski created a practically and scientifically grounded theory of actor's stage impersonation known as Stanislavski's system, which formed a number of generations of talented actors and directors in Ukraine and abroad. The transition of an individual into the psychic reality of another person, the short process of identification with the one, and the temporary fulfillment of their social and role functions are the essence of impersonation. The success of this process is connected with the actor's emotional experience of their role, which is determined by the 
personality of the actor themselves, their attitude to the truth of life onstage, specific super-tasks for the realization of a certain action, the proposed circumstances of the role and the play, the collective nature of theatrics in general, which is objectified in the actor's creative activity both as a performer and as an actor.

Key words: Stanislavski's system, Stanislavski, method, art, actor, role, stage impersonation, emotional experience, super-task, proposed circumstances.

Вступ. Синтетична природа театру забезпечує йому відносну перевагу перед оповідальними видами мистецтва (наприклад, літературою), що полягає в особливій наочності сценічної дії, й зображальними видами мистецтва (живопис, скульптура, кіно, фотографія тощо). Вона міститься в високій динаміці й демонстрації подій та характерів силою впливу театрального дійства на глядача. Глядач одночасно зазнає активного впливу на собі змісту твору, покладеного в основу театральної вистави, гри акторів й емоційнопсихологічної атмосфери спектаклю.

Особливості художньої творчості й світ образного сприйняття наочно втілюються засобами сценічного мистецтва. У процесі реалізації сценічного дійства актор, використовуючи оповідальний матеріал, доповнений допоміжними засобами, створює сценічний образ й в такий спосіб прагне донести до глядачів ідейно-художній зміст твору. Оповідальний матеріал значною мірою визначає його творчість, проте актор забарвлює конкретну роль своєю індивідуальністю, пропонує свою інтерпретацію твору, суттєво пов'язану 3 психологічними основами акторського мистецтва. Актор виступає, таким чином, одночасно і як творець, і як виконавець.

Аналіз останніх досліджень і публікацій. Теорія акторського образного перевтілення на основі іiі перевірки практикою акторської майстерності Костянтина Сергійовича Станіславського стала предметом практичного інтересу театральних вітчизняних та зарубіжних діячів протягом усього XX початку XXI ст. Систему К. Станіславського театральний педагог Ю. Стромов розглядає як таку, що просякнута ідеєю реалізації оптимального «шляху до перевтілення» [8, с. 35]. Розумінням гармонійного «співвідношення форми сценічного майданчика, складу глядачів, структури акторської гри й характеру драматургії», яка духовно задовольняє глядача визначається театрознавцем й літературознавцем О. Гвоздєвим як система театру [2, с. 9]. В. Галацькою в статті «Засоби декодування принципів режисерської системи К. С. Станіславського в театральній журналістиці незалежної України» [1, с. 197] висвітлено особливості інтерпретації термінів системи К. Станіславського в журнальній театральній критиці незалежної України. Зокрема, сучасна театральна публіцис- 
тика аналізує концепти сценічного перевтілення актора: наскрізна дія, творче надзавдання, емоційний темпоритм, запропоновані обставини й ін. у контексті духовності та естетичної цінності [1, с. 203]. О. Клековкін проводить паралель у «Поетиці» Аристотеля між «аристотелівським» («драматичним») театром 3 вишуканою імітацією переживання, театром «суцільної дії», який обстоював К. Станіславський із своїми однодумцями та «теорією перевтілення» К. Станіславського [3, с. 14] у контексті сучасної домінанти «аристотелівського театру», в порівнянні з яким інші моделі театру бачаться автором чудернацькими збоченнями або дитячими забавками [3, с. 15]. Д. Черкасський порівнює досвіди двох найвпливовіших театральних педагогів з сценічної майстерності XX ст.: Методу Лі Страсберга, який називають американською версією системи К. Станіславського, та власне Системи К. Станіславського [9]. Автор аналізує періоди роботи Станіславського над своєю Системою, співвідносить рівні уявлень про Систему Станіславського і Метод Страсберга, виявляючи в них подібності та відмінності.

Виклад матеріалу дослідження. Визначному російському режисерові, акторові, педагогу, теоретику театру, почесному академікові Російської академії наук (1917 р.) К. С. Станіславському (справжнє прізвище Алексєєв, 1863-1938) належать створені ним методологія акторської творчості й техніка органічного перевтілення в образ («система Станіславського»). У своїй праці «Робота актора над собою» дослідник формулює й обгрунтовує основні принципи перевтілення як наріжного каменя сценічної майстерності. Зазначений мистецтвознавчий концепт є винятково важливим у розумінні кордоцентричної натури українців як характерної особливості їх ментальності й специфічності національного театру, поєднаної з поширенням у західноєвропейській сценічній практиці бінарної об’єктивізованої «школи вдавання» [1, с. 197].

Головним принципом функціонування професії артиста К. Станіславський вважав внутрішню природну налаштованість до душевного переживання, втілюваного за специфічних творчих обставин об'єктивації ролі: за умов активної трансформації драматургічних задумів та справжніх пристрастей за переконливо правдоподібних обставин [6, с. 105].

Створення переконливого сценічного образу з невід'ємними механізмами перевтілення потребує не лише високого сценічного професіоналізму, а й належного загального культурно-освітнього рівня актора. Соліст Маріїнського театру в Санкт-Петербурзі Ф. Стравинський на зламі XIX-XX ст., наприклад, перед розучуванням оперної партії вивчав книги про той період, в якому діяв його герой, читав оперну партитуру й знайомився 3 лібрето, пристосовуючись до епох, до характерів всіх задіяних у виставі осіб, знав 
практично напам'ять драматичні подробиці розвитку подій $[4$, с. 72-73] як запоруку успішного сценічного перевтілення. Тому актор користувався в публіки великим успіхом при виконанні найрізноманітніших ролей: Мефістофеля, Фарлафа, Івана Сусаніна та ін. Вокально-виконавську практику досвідчених колег зі столичних у російській імперії Маріїнського й Александринського театрів засвідчив і творчо розвинув Ф. Шаляпін. У голосі, у позі й кожному рухові відтворюваного духа зла, виблискуючих полум'ям очах відчувалося, що на сцен справді всемогутній, саркастично налаштований щодо слабостей людських Мефістофель [4, с. 118].

Граючи, цей визначний артист перетворювався, тонко схоплюючи характер кожного окремого персонажа. Гігантську інтелектуальну роботу артистів з самовдосконалення К. Саксаганський йменує «надзавданням» у благородній справі служіння глядацькій аудиторії й театрові.

Творчо-сценічне сходження від «природного себе» до персонального втілення художнього образу потребують високоякісної фахової підготовки актора, володіння ним мистецтва інтерпретації персонажа на сцені або перед камерою засобами міміки, жестикуляції й голосу. Чільне місце в системі К. Станіславського тому посідає його теорія «вживання у роль», тобто ототожнення актора 3 його персонажем. Таке мистецтво потребує поглибленого вивчення належної режисерської й акторської техніки 3 властивою їй сукупністю вправ та прийомів [5, с. 408]. Спорідненою 3 системою К. Станіславського $є$ методика орієнтованості видатного німецького драматурга, поета і режисера Б. Брехта (1898-1956) на тезу про об’єктивність та самодисципліну актора. Досліджуючи феномен акторського перевтілення, митець підкреслює, що основним методом гри має бути «показ».

У США система К. Станіславського була успадкована американським режисером, актором і продюсером Лі Страсбергом та американською акторкою й театральним педагогом Стеллою Адлер. Російський дослідник Д. Черкаський зазначає, що незважаючи на різні підходи до деяких педагогічних аспектів системи К. Станіславського, його система й метод Л. Страсберга єдині в тлумаченні законів акторської майстерності [9, с. 149]. Нині система російського майстра $\epsilon$ домінуючою методологією підготовки американського актора, включаючи в себе фізичну й вокальну підготовку, розвиток його емоційно-чуттєвої природи, формування імпровізаційних навичок.

Головною засадничою основою художньої системи К. Станіславського виступає принцип життєвої правди, який вимагає принципово відділяти сценічну правду від принадної брехні, пов'язуючи акторське мистецтво лише 3 правдивістю втілення образу на сцені. 3 метою уникнення сценічних похибок 
варто культивувати в себе відповідальність за правдиве відображення на сцені реальностей життя, кожного разу звітуючи перед собою про результати проведення сценічного дня. Сутність вимог К. Станіславського не припускає прощення ні собі, ні своїм послідовникам за псевдотеатральність, якою б вона не була привабливою.

За принципом зорієнтованості на реалізацію надзавдання усі компоненти фахової системи підготовки актора мають бути залежними від основної мети мобілізації його творчого потенціалу на об'єктивацію авторського й режисерського задумів. Надзавданням $є$ те, задля чого художник прагне поширення своєї ідеї в свідомості людей, що $\epsilon$ найзаповітнішим бажанням митця. Реалізація надзавдання зумовлюється наявність його ідейної переконаності, цілеспрямованості й відданості життєвим принципам та ідеалам суспільно-перетворюючих здатностей мистецтва. Тому неприпустимі похибки в доборі сценічного матеріалу, режисерських методів і методик, визначенні концептуального арсеналу технічних прийомів і засобів вираження.

Реалізація принципу активності й дії матеріалізується мистецьким професіоналізмом з використанням ретельно продуманих режисером сценічних методик i, зважаючи на фізичні дані, загальнокультурного й фахового інтелекту, спроможності актора до сценічного перевтілення й добре керованої імпровізації.

У відповідності з принципом органічності театральне мистецтво має сприйматися як різновид колективної творчості [5, с. 279]. Особлива роль у цьому належить режисерові, який задає загальне ідейно-художнє спрямування сценічного дійства й організовує всіх учасників спектаклю на виконання запрограмованого завдання. Йому, в концептуальному баченні К. Станіславського, мають бути внутрішньо притаманними посилені інтуїтивно підсвідомі артистичні відчуття, розвинута емоційна пам'ять, яку визначний реформатор театру називає афективною (пам'ять серця), висока сценічна увага й щедра фантазія [7], [1, с. 197].

В ідейному плані акторське мистецтво, будучи виконавським, грунтується на творчому продукті літературної діяльності драматурга - п’єсі або тексті лібрето, музиці композитора, а в організаційно-технічному аспекті на постановочній діяльності режисера. Проте, глядачем оцінюється саме актор як суб'єкт, під впливом якого в його свідомості сформувалося почуття задоволеності або незадоволеності від баченого на сцені та пережитого в душі. Привабливий вигляд актора, його красивий голос й підвищена емоційність натури, пристрасть - все це постає перед погано обізнаним у театральній майстерності глядачем високим мистецтвом втілення в образ, а виконавець ролі асоціюється в глядача 3 надзвичайно талановитим митцем, й нерідко сам актор стає впевненим у цьому [6]. 
К. Станіславський жорстко критикував подібне псевдомистецтво. Деякі актори, зазначав він, не потребують ні характерності, ні перевтілення, оскільки вони пристосовують будь-яку роль до себе, покладаючись винятково на привабливість своєї зовнішності й лише на цьому будують вони свою успішність, й без цього вони безсилі [7, с. 239]. Відомо чимало випадків, критично підсумовує цей визначний дослідник театру, коли навіть природна сценічна чарівність стала причиною духовної трагедії актора, технічні прийоми якого обмежувалися самозамилуванням [7, с. 269]. 3 відвертою зневагою ставився К. Станіславський до проявів акторського нарцисизму: «Ви більше любите себе в ролі ..., наставляє художник, - Полюбіть роль у собі» [7, с. 240].

Принцип перевтілення є визначальним принципом системи К. Станіславського. Дотримуючись його, актор виходить на сцену з метою якісного розкриття перед глядачем створюваного ним образу, а не для самореклами.

Глибинна суть системи К. Станіславського - поставити актора в запрограмовані рольові обставини й спонукати діяти «від себе» під час роботи над роллю - реалізується лише в контексті єдності побудованого образу та власної живої природи актора, оскільки в створенні сценічного образу в ролі головного матеріалу використовується унікальна індивідуальність самого актора.

Процес перевтілення відбувається органічно й не зводиться до спрощеної імітації й суто зовнішнього зображення лише тоді, коли актор зі сцени може щомиті сказати про себе: «Я єсмь». 3 органічної єдності сценічних дій, відчуттів, переживань, тілесної пластики й динаміки, живого голосу актора постає переконливий образ. Належного значення майстер надавав характерній зовнішності актора та мистецтву його перевтілення. Кожен артист має пред'явити на сцені глядачам неповторний образ, пам'ятаючи, що нехарактерних ролей не існує [6, с. 250].

В умовах непримиренної боротьби з проявами формального, механічного підходу до акторської освіти система К. Станіславського набула всесвітнього визнання як дієва методологія подальшого творчого розвитку театральносценічного мистецтва. Адже формальне засвоєння знань, без глибокого проникнення в їх суть може завдати професійно-театральній справі великих втрат. 3 прикрістю доводиться, зокрема, констатувати, що на театральних підмостках й кінознімальних майданчиках набуває актуальності хибна практика так званого «типажного принципу» створення вистави або фільму. Цей принцип полягає в тому, що для певної ролі режисером вибирається актор за типажною подібністю й без будь-якого якісного перевтілення, а не артист, здатний переконливіше зіграти іï, створити оригінальний художньо-сценічний образ $[8$, c. 13]. За такого спрощеного вибору актора на роль, яким $є$ «типажний 
принцип», сценічно-акторська техніка зводиться до пояснення тези «у запропонованих сценічних обставинах» без будь-яких умов, пов'язаних 3 акторською майстерністю образного перевтілення.

Стати іншим, залишившись собою, - ось найважливіша вимога, яка показує процес творчого перевтілення актора в принциповій відповідності зі системою К. Станіславського. Винятково важливо, щоб актор постійно зберігав й примножував на сцені внутрішнє почуття усвідомлення себе. К. Станіславський наполягав, щоб актор, інтегруючи в собі внутрішні й зовнішні риси персонажа, переконливо ототожнюючись з образом, контролював «свій сміх і свої сльози. I в цьому двоїстому житті, в цій рівновазі між життям та грою полягає мистецтво» [5, с. 407].

3 ініціативи К. Станіславського в 1898 р. було відкрито Московський художній театр (МХАТ). Головна роль у ньому належала режисерам, які втілювали за допомогою акторів задуми авторів на сцені. У цьому театрі сформувалася потужна плеяда талановитих артистів в особі М. Андреєва, I. Москвіна, В. Качалова, О. Кніппер-Чехової, А. Тарасової та ін.

Для тогочасного театрального мистецтва було характерне розмаїття форм i стилів, художніх концепцій та театральних теорій. У них поєднувалися умовність i реалізм, модернізм і академізм. З'явилась велика кількість театральних студій. Прихильний, зокрема, до умовного театру В. Мейєрхольд разом з В. Комісаржевською - актрисою психологічного театру - ставив п'єси на сцені Александринського театру в Петербурзі. Виникали й камерні форми театру: театр одного актора, пантоміма та ін. Талановитими послідовниками революційно-перетворюючої діяльності К. Саксаганського стали й видатні майстри української драматургії й театру М. Куліш й Л. Курбас, але безжально заплатили своїм життям сталінському тоталітарному режимові. Лише з середини 1950-х рр. почалося оновлення в галузі культури, яке торкнулося й театрального мистецтва.

Зрозуміло, й нині на різних театральних сценах створюється велика кількість високоякісних вистав, де актори здійснюють своє творче служіння на засадничих принципах системи К. Станіславського, правдиво переживаючи свої рольові образи, творчо перевтілюючись в них, правдоподібно створюючи сценічний матеріал. Будь-яке ж зовнішнє наслідування принципово несумісне 3 творчою системою видатного реформатора сцени, мета якої спонукати до життя змістовний і конструктивний процес сценічно-театральної діяльності.

Висновки. К. С. Станіславський створив практично й науково обгрунтовану теорію образного перевтілення актора, відомою під назвою «Система Станіславського», що сформувала цілі покоління талановитих акторів і режисерів 
в Україні й за кордоном. Перетворення конкретної людини в психічну реальність іншої людини, нетривалий процес ідентифікації з нею, тимчасове виконання ії соціально-рольових функцій і $є$ перевтіленням в образ. Успішність цього процесу пов'язана з переживанням актора своєї ролі, яке визначається особистістю самого актора, ставленням до життєвої правди на сцені, конкретними надзавданнями для реалізації певної дії, пропонованими обставинами ролі та п’єси, колективною природою сценічного мистецтва загалом, яке об'єктивується в творчій діяльності актора одночасно як виконавця і як актора.

Перспективи подальших досліджень вбачаються у висвітленні специфіки епічного театру Б. Брехта.

\section{Список використаних джерел}

1. Галацька В. Л. Засоби декодування принципів режисерської системи К. С. Станіславського в театральній журналістиці незалежної України / В. Л. Галацька // Вісн. ХДАК. - Вип. 43. - Харків, 2014. - С. 196-204.

2. Гвоздев А. А. О смене театральных систем / А. А. Гвоздев // О театре : Временник Отдела истории и теории театра Государственного института истории искусств : сб. ст. - Ленинград : Academia, 1926. - С. 7-36.

3. Клековкін О. Ю. Theatrica : Архітектура драми : історикотермінологічний конспект / О. Ю. Клековкін. - Київ : Арт Економі, 2012. - 85 с.

4. Петелин В. Восхождение, или Жизнь Шаляпина (1894-1902) / В. Петелин. - Москва : Центрполиграф, 2000 . - 648 с.

5. Станиславский К. С. Собр. соч. В 9 т. Т. 1. Моя жизнь в искусстве / К. С. Станиславский. - Москва : Искусство, 1988. -622 с.

6. Станиславский К. С. Собр. соч. В 9 т. Т. 2. ч. 1. Работа актера над собой. Работа над собой в творческом процессе переживания. Дневник ученика / К. С. Станиславский. - Москва : Искусство, 1989. - 511 с.

7. Станиславский К. С. Собр. соч. В 9 т. Т. 3. ч. 2. Работа актера над собой. Работа над собой в творческом процессе воплощения. Материалы к книге / К. С. Станиславский ; Общ. ред. А. М. Смелянского, вступит. ст. Б. А. Покровского, комент. Г. В. Кристи и В. В. Дыбовского. - Москва : Искусство, 1990. - 508 с.

8. Стромов Ю. А. Путь актера к творческому перевоплощению / Ю. А. Стромов : учеб. пособие для театр, и культ.-просвет, учеб. заведений. Москва : Просвещение, 1980. - 80 с.

9. Черкасский С. Д. Система Станиславского и метод Страсберга: опыт сравнительного анализа = Stanislavsky system and Strasberg's method: an approach to comparative analysis / С. Д. Черкасский // Известия Рос. Гос. пед. Ун-та им. А. И. Герцена. - 2011. - №143. - С. 143-150. 


\section{References}

1. Halatska, V. (2014). Tools for Decoding Principles of K.Stanislavski's Directing System in the Theater Journalism of Independent Ukraine Visnyk Kharkivskoi derzhavnoi akademii kultury [Bulletin of the Kharkov State Academy of Culture], issue 43, pp. 196-204.

2. Gvozdev, A. (1926). On the replacement of theatrical systems. $O$ teatre : Vremennik Otdela istorii i teorii teatra Gosudarstvennogo instituta istorii iskusstv [On the Theater: The Cronicle of the Department of History and Theory of Theater of the State Institute of Art History], pp. 7-36.

3. Klekovkin, O. (2012). Theatrica: The Architecture of Drama: Historical and terminological notes. Kyiv: Art Ekonomi.

4. Petelin, V. (2000). Climbing, or the Life of Chaliapin (1894-1902): Moscow: Tsentrpoligraf.

5. Stanislavski, K. (1988). Collection of works. In 9th vol. vol. 1. My life in the art. Moscow: Iskusstvo.

6. Stanislavski, K. (1989). Collection of works. In 9th vol. vol. 2. Part 1. The actor's self-improvement. Self-improvement in the creative process of impersonation. Diary of a student. Moscow: Iskusstvo. Stanislavski, K. (1990). Collection of works. In 9th vol., vol. 3. Part 2. The actor's self-improvement. Self-improvement in the creative process of impersonation. Materials for the book. Moscow: Iskusstvo.

7. Stanislavski, K. (1990). Collection of works. In 9th vol., vol. 3. Part 2. The actor's self-improvement. Self-improvement in the creative process of impersonation. Materials for the book. Moscow: Iskusstvo.

8. Stromov, Yu. (1980). The way of the actor to creative impersonation. Moscow: Prosveshchenie.

9. Cherkasskii, S. (2011). Stanislavski's system and Strasberg's method: an approach to comparative analysis. Izvestiya Rossiiskogo gosudarstvennogo pedagogicheskogo universiteta im. A.I. Gertsena [Izvestiya of the Russian State Pedagogical University named after A.I. Herzen], no.143, pp. 143-150.

(C) Хлистун О. С., 2017 